\title{
The politics of opting out: explaining educational financing and popular support for public spending
}

\section{Citation}

Busemeyer, M. R., and T. Iversen. 2014. "The Politics of Opting Out: Explaining Educational Financing and Popular Support for Public Spending." Socio-Economic Review 12 (2) (March 26): 299-328. doi:10.1093/ser/mwu005.

\section{Published Version}

doi:10.1093/ser/mwu005

\section{Permanent link}

http://nrs.harvard.edu/urn-3:HUL.InstRepos:13364825

\section{Terms of Use}

This article was downloaded from Harvard University's DASH repository, and is made available under the terms and conditions applicable to Open Access Policy Articles, as set forth at http:// nrs.harvard.edu/urn-3:HUL.InstRepos:dash.current.terms-of-use\#OAP

\section{Share Your Story}

The Harvard community has made this article openly available.

Please share how this access benefits you. Submit a story.

Accessibility 


\title{
The Politics of Opting Out:
}

\section{Explaining educational financing and popular support for public spending}

\author{
Marius R. Busemeyer, University of Konstanz \\ Torben Iversen, Harvard University
}

\begin{abstract}
:
In this paper, we address two empirical puzzles: Why are cross-country differences in the division of labor between public and private education funding so large, and why are they politically sustainable in the long term? We argue that electoral institutions play a crucial role in shaping politico-economic distributive coalitions that affected the original division of labor in education financing. In PR systems, the lower and middle classes formed a coalition supporting the establishment of a system with a large share of public funding. In majoritarian systems, in contrast, the middle class voters aligned with the upper income class and support private education spending instead. Once established, institutional arrangements create feedback effects on the micro-level of attitudes, reinforcing political support even among upper-middle classes in public systems. These hypotheses are tested empirically both on the micro level of preferences as well as on the macro level with aggregate data and survey data from the ISSP for 20 OECD countries.
\end{abstract}

Key words: education, political economy, redistribution, preferences, equality

JEL Classification: 124, H52 


\section{Introduction: The puzzle}

Preferences for public polies are commonly modeled as a function of individual income, risk, or sometimes ideological frames. Almost never is the choice modeled as one between public and private alternatives. We will argue in this paper that the availability of private alternatives, of opting out, makes a big difference to the politics of public policies. In a range of policy areas -- such as pensions, old age care, healthcare, daycare, and, our focus, education -- public and private alternatives compete with each other. Borrowing a terminology from Hirschman, what matters then is not only "voice" (voting) but also "exit" (choosing private alternatives), and the latter, we argue, affects the former.

Welfare states vary greatly in terms of whether social services are provided by the government or privately. This is a puzzle because democratic politics is supposed to lead to increased demand for public spending and a gradual phasing out of private social service provision. The logic is that as public spending rises, voters have to shoulder a rising tax burden and the ability and willingness of voters to pay for private services in addition to public services should correspondingly decrease. Instead, voters should become more interested in improving the quality of public services. Empirically, however, we observe a large variation in the share of private financing in social services such as education (see figure 1). In some countries, education is provided and financed with public monies, whereas in others, voters seem happy to shoulder a large share of educational investments themselves. Moreover, these institutional settings are relatively stable over time, i.e. they most likely reflect underlying political equilibria. How can this be explained?

The question of education financing matters because the structure of funding has notable effects on the distribution of spending, which in turn affects wage, income and wealth inequality. Private alternatives to public spending do not play any role in much of the comparative political economy literature, but at least in the case of education they are critical to explaining a range of distributive outcomes (Busemeyer 2014). In this paper we argue that electoral institutions influence the formation of distributional coalitions, which in turn affect the division of labor between public and private sources of funding through a network logic. Once the composition of spending is "tilted" in one direction or another, complementarities in private decisions to invest in education reinforce a particular structure of funding, which in turn affects individual preferences over public policies. 
Figure 1: Share of education funding from private sources in OECD countries, 2007.

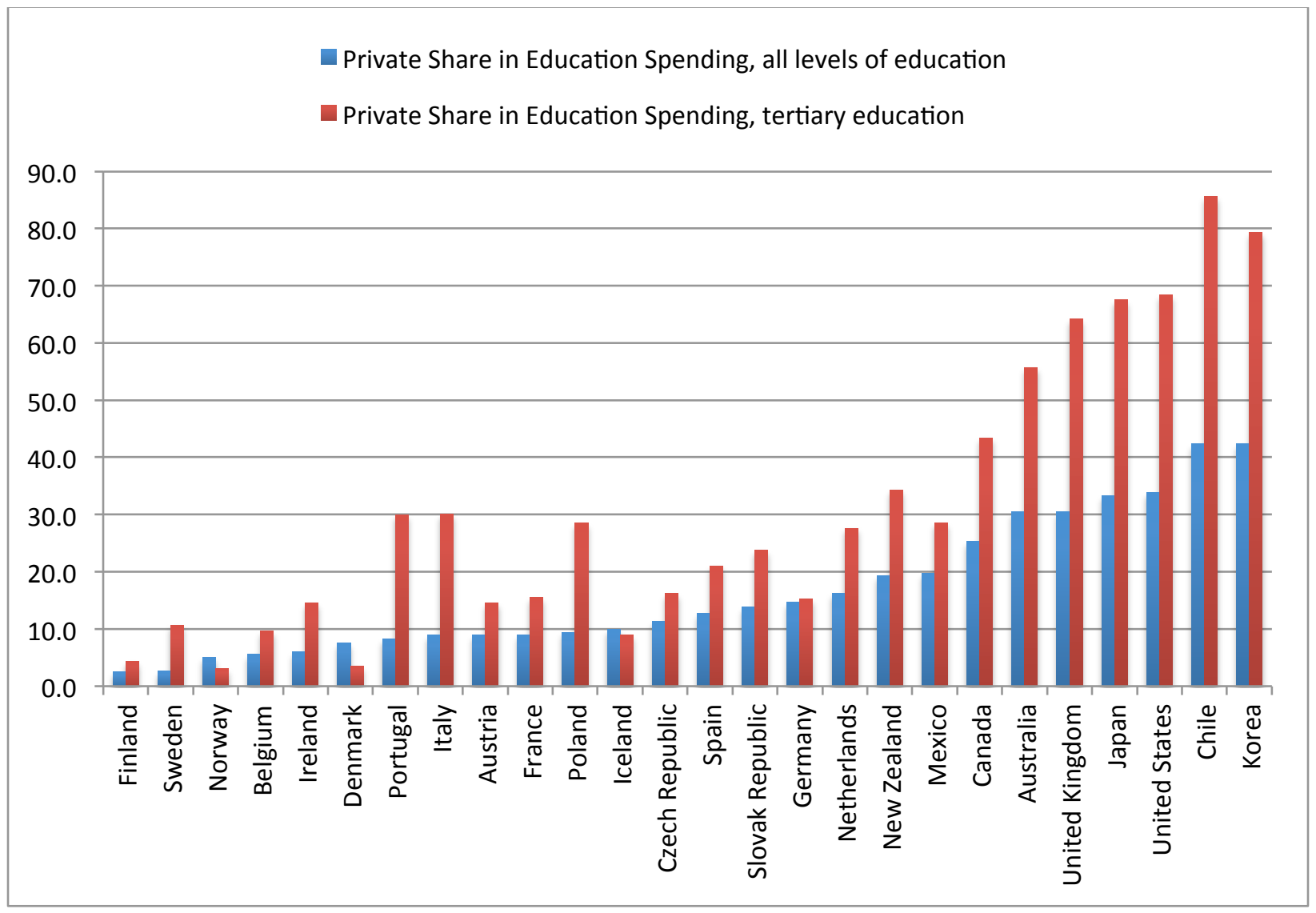

Source: OECD, 2010: Education at a Glance, 233, 235.

A stark implication of our model is that the relationship between income and support for public spending on education should vary depending on the electoral system and the composition of spending. In PR countries with large public systems, network effects transmitted through the fiscal system push high-income groups, who are concerned with high-quality education for their children, to push for more public spending in contrast to low-income groups, who are more concerned with current consumption. This is particularly true when the secondary and higher education systems are stratified because this concentrates benefits on the rich (Ansell 2008, 2010; Busemeyer 2012). Conversely, in majoritarian countries with high levels of private financing, high income groups who can shoulder substantial private costs for education will oppose public spending because it undermines the returns on private investments, whereas low-income groups who cannot afford private education will favor more public spending that is de facto more targeted to these groups. This is particularly true when income inequality is high. To our knowledge there is no existing model that has this implication, and it does not necessarily apply to other spending areas. Our theoretical framework is rooted in the rational choice paradigm, but we add an important component to this approach by emphasizing the importance of social networks for individual choices (see also Abrams et al. 2010). Wilensky suggested that "education is different" (1975, 
p. 3), and our model explains why (although the model may be increasingly applicable to other policy areas). We test it on both macro-level spending data and micro-level public opinion in a large sample of Western OECD countries.

\section{Existing literature}

After education had long been neglected in comparative political science and political economy, it has enjoyed growing scholarly interest in recent years (Busemeyer/Trampusch 2011). The debate on Varieties of Capitalism ( $\mathrm{VoC}$ ) played a crucial role in raising the interest of main-stream political science in topics such as the political economy of skills and training (Culpepper 2003; Finegold/Soskice 1988; Iversen/Soskice 2001; Streeck 1989; Thelen 2004). A few contributions recognize the importance of the connection between skill formation regimes and the welfare state (Busemeyer/Nikolai 2010; EstévezAbe et al. 2001; Iversen/Stephens 2008), but the exact nature of the causal mechanisms linking these two areas is still unexplored.

Following Ansell $(2008,2010)$, we argue that the politics of educational investments can and should be treated as a contentious issue in the redistributive conflict between socio-economic classes similar to other social policies. In line with this argument, Ansell's work as well as the work of others (Boix 1997, 1998; Busemeyer 2007, 2009; Castles 1989, 1998; Schmidt 2007) shows that the level and distribution of public investments in education are strongly shaped by partisan politics and changes in the balance of power between politico-economic interests. Private education spending has not been studied as extensively as public spending. Exceptions are Wolf (2009) and Wolf and ZohInhöfer (2009) who identify union density, partisan power and religious heritage as important determinants of differences in private spending on education. Yet these authors do not model the simultaneous individual choices of voting for and against public spending and choosing a level of private spending. We will show that the interdependencies of these choices, and the educational choices of others, affect individual preferences and the analysis of the role of partisanship.

More recently, scholars have moved from the macro to the micro level of individual attitudes towards education policies and educational choices. There is a large literature in educational sociology and comparative education research on the individual and institutional determinants of educational choices as individuals move through the stages of their educational careers (for a recent overview and example, see Breen et al. 2009). This literature provides important insights into how educational institutions affect patterns of educational stratification (e.g. Breen/Jonsson 2005; Pfeffer 2008; Stocké 2007), but it does not look at policy preferences of (working-age) individuals with regard to the politically preferred design of education systems. The distinction between education policy preferences and actual choices over educations is important, however. New scholarship in comparative political economy and welfare state research has started to identify the most important individual and institutional determinants of education policy preferences (Ansell 2010: Chapter 4; Busemeyer 2012; Busemeyer et al. 2009; Busemeyer/Jensen 2012), building on an earlier literature that studied the feedback effects of existing welfare state institutions on preferences (Andreß/Heien 2001; Blekesaune/Quadagno 2003; Jaeger 
2006, 2009; Svallfors 1997, 2004, 2010). Although the empirical evidence is mixed, the general expectation of this literature is that institutions create positive feedback effects, contributing the longterm political sustainability of existing institutional arrangements. So private educational choices cannot be separated from educational policies, which in turn are affected by electoral preferences; education choices and policy preferences interact. .

Our contribution to these literatures is two-fold. First we add to our knowledge of the political and institutional determinants of cross-country differences in the division of labor in the financing of education. Specifically, building on Iversen and Soskice (2006), we focus on the role of electoral institutions shaping politico-economic distributive coalitions that are associated with particular crossnational patterns of educational investment. Second, we provide a game-theoretic analysis of individual educational choices when there is an option to opt of the public system, and we show that this has implications for how we understand voter preferences for public policies. The existing research on preferences focuses on the cross-level interaction between attitudes and educational institutions (Ansell 2010; Busemeyer 2012; Busemeyer/Jensen 2012), and we show that this interaction is a consequence of network effects in educational choices.

\section{The argument}

We propose in this section how the funding puzzle can be solved using an institutional network model of educational investment. In this paper we consider only democracies and the key institution is the electoral system. Yet the effects of the electoral system go through the strategically interdependent behavior of voters, and before we can understand the macro-level effects of institutions we therefore need to consider the micro-level logic. We differentiate preferences over funding system by income class but focus on the preferences of middle class voters under the assumptions that middle class parties are needed for a legislative majority and that this majority chooses the educational system (we modify this assumption below). We then proceed to explain how the electoral system "tips" middle class preferences toward favoring either more private or more public spending, which determines the relationship between income and preferences.

Our analysis refers to secondary and post-secondary education since primary education is mandatory in all countries we consider and overwhelmingly publicly financed (even though there are some countries with a strong sector of independent primary schools). One reason that primary education is almost universally public is that there are strong positive externalities of primary education spending - it is a virtual requirement for all workers in a modern economy to have basic skills - so the middle and upper middle classes have a reason to always support public schooling for the lower classes. Since our compositional spending data include all educational spending, the private component never exceeds one third of total spending, but it increases sharply as we look at secondary and especially tertiary education (see figure 1).

Our analysis assumes that individual preferences over policies are driven by material self-interest, broadly construed to include altruistic concerns for the welfare of children. We recognize that this is a simplifying assumption used in part for theoretical tractability, but we also believe it captures an 
important aspect of the politics of educational funding. In particular, we think it would be very difficult to understand the cross-country differences in class divisions over public education without attention to how institutional incentives shape self-interest. At the same time we will acknowledge other potential influences on preferences in the empirical analysis.

\subsection{The individual choice over educational spending}

We assume that the typical middle class family has one or two children, where the adults have already acquired an education, but where their children have not. Parents are assumed to be altruistic and pay a significant portion of their children's educational bill. The middle class voter now has two decisions to make: a private economic one and a political one. The economic one is how much to invest privately in their children's education; the political one is whether to support public or private financing of education. We will show that the two decisions are interconnected, and that individual preferences over educational policy depend on the private choices people make in investing in education.

We follow Ansell (2010) and assume that low-income classes have a preference for public financing of education since public subsidization reduces the marginal cost of education and enables children to acquire an education that many could otherwise not afford. The gains for the lower classes come via two main channels. First, if access to public education is universal, public financing has a redistributive component since the benefit makes up a greater share of income for those at the lower end of the distribution. ${ }^{1}$ Second, because the costs of private financing are inversely related to the ability of parents to put up collateral (wealth and earnings) for educational loans, the savings of lower income individuals from public subsidies are greater.

The logic for upper income classes is exactly the reverse. ${ }^{2}$ They pay more into a public system via taxes than low-income groups and their costs of financing their own children's education privately are lower. Furthermore, being highly educated themselves, they have an incentive to limit the supply of skills to maintain a high wage premium on education. While they want their own children to be educated to enjoy this premium, they have no interest in others being able to do the same. A privately funded system of education provides effective barriers to less affluent children, and private funding therefore raises the returns to education for the well-off.

The middle class is located between these two groups, both economically and in terms of policy preferences. On the one hand, a private system of financing reduces the tax burden to fund the education of the lower classes, and it creates a higher wage premium for children of the middle class if

\footnotetext{
${ }^{1}$ A reviewer raised the question of whether this is also true for higher education. We believe it almost certainly is for rich democracies. Thus, Sefton (1997) shows for the UK case (in 1993) that the ratio of spending per person in the bottom quintile group to that of the top quintile group is 0.7 . If we then take into account the fact that in the UK in 1993 the top quintile received $41.2 \%$ of total household income while the bottom quintile received $7.5 \%$ (or .18 of what the top received), then it is clear that even a moderately regressive tax would be a net transfer to the bottom quintile.

${ }^{2}$ Again, this assumes democracy. Ansell (2010) proposes a different logic before mass democracy. Since the franchise was initially restricted to the wealthy they favored more public spending as industrialization proceeded. But as the franchise was gradually extended to the middle classes and then the poor, they increasingly favored private alternatives, which is the starting point for our analysis.
} 
their cost of private funding is sufficiently low. Middle class voters also tend to have intermediate skills that are the most wage-sensitive to an increase in the supply of skilled workers from the lower classes. On the other hand, access to credit is constrained for at least some in the middle class, and the cost of educational loans can be prohibitively high for many. Finally, some in in the middle class benefit from the redistributive aspects of public spending. This could sway the middle class towards supporting public funding.

Given the pivotal position of the middle class, the preferred structure of funding depends critically on which side the middle class comes down on. So a key question is how individuals decide whether or not to support public spending on education. We propose that this choice depends on whether individuals themselves have an incentive to opt out of the public system by paying a substantial share of the costs of education themselves. If so, they have little reason to support a tax-financed spending that mainly benefits those who stay in the public system. If they do not have a private incentive to opt out they come to depend on the public system and will favor taxation to fund their children's education. What decides, then, whether individuals opt out?

We assume here that choosing to pay for your children's education yields advantages in terms of school choice and quality. This is clearly the case for privately funded secondary schools and universities, but it also holds if there are economic barriers to entering the best public schools. The US is a prime example because tuition and fees at public schools are much higher for out of state students, so access to the best schools depends on ability to pay. In England public universities have discretion to charge fees up to a maximum of $£ 9000$ and the best do. The ceiling is expected to rise, which will result in more differentiation between tiers of schools. A differentiated public system also induces wealthier parents to spend on private tutoring, summer schools, etc. There are consequently benefits of opting out, or at least supplementing public spending with your own money. If quality education is a normal good, demand is rising in income, whereas the costs of financing education privately will be falling in income.

Yet the affordability of opting out for any individual depends on how many others opt out. Since affordability is declining in taxes paid into the public system, for any individual to partially or fully opt out of the public school system and pay (some) for themselves, a sufficient number of other parents must have done the same. This is reinforced by a rising skilled wage premium as lower-income parents are increasingly priced out of higher education.

We can formalize this logic using a simple network or strategic complementarities game (originally outlined in Schelling 1978). The idea is that for any individual to opt out of the public system and pay for themselves, a critical mass of other parents must have done the same. When all or most people send their children to public schools and pay for this through taxes, only a small number of very wealthy people will opt out. But if a substantial number of parents pay for private alternatives, the tax burden of the public system declines, the wage premium increases, and more people can afford to opt out, and so on. Furthermore, a smaller public sector might indicate a selection effect in the sense that the quality difference between public and private schools increases as more and more of the wealthy opt out. The point at which it is more attractive for an individual to opt out than to stay put is what Shelling calls a critical mass point. The critical mass point will be low for the wealthy but will rise as income declines. 
For some low income people this point will never be reached and they will hence never support a private system.

If the critical mass points are a function of income, it is sensible to conjecture that the distribution of these points is inversely related to the income distribution. Since the income distribution is right-skewed the distribution of critical mass points will be left-skewed, so that there is an in-built asymmetry that favors public over private provision. This is illustrated in Figure 2 (although our conclusions do not depend on the skew). In the left tail there are just a few wealthy people who will opt out (when others don't), but then the numbers increase more steeply until one reaches income groups where fewer and fewer are able to opt out even when most others do. Again, some will likely never opt out regardless of how many others do, so a fully private system is infeasible. This means that the share opting out may be much less than 100 percent.

Figure 2. The distribution of critical mass points in choosing private education when the incentive to opt out is a function of income (the $y$-axis shows the frequency of opting when a particular share of others do).

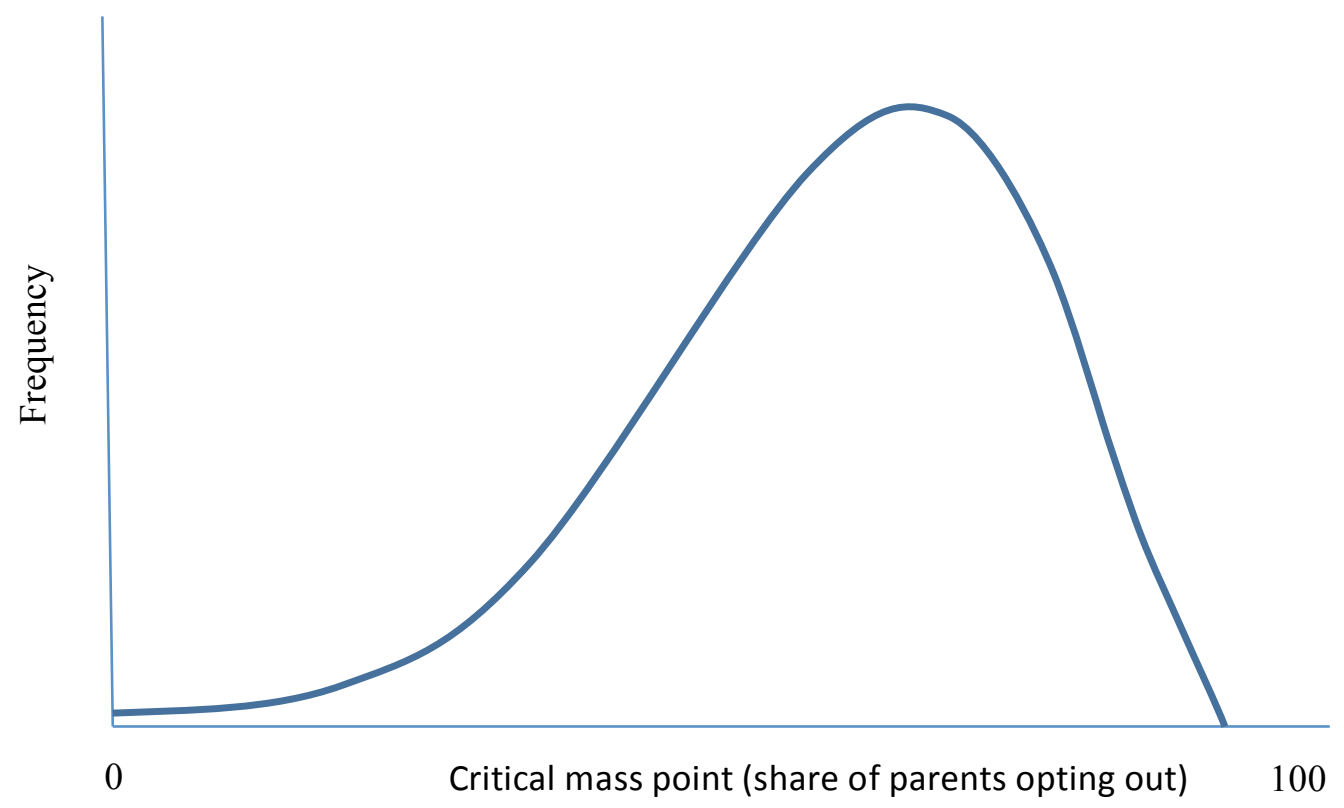

Figure 3 is simply the distribution in Figure 2 transformed into a cumulative probability function, where the $x$-axis measures the expected share of individuals who opt out of the public system, while the probability of an individual opting out is recorded on the $y$-axis. Since the probability of choosing private alternatives must be equal to the actual share of people who do, equilibria are located on the 45-degree line. Based on the distribution in Figure 2 there are three such equilibria. One of these, the one in the middle, is unstable, however. This is the "tipping point" because any small deviation from this point will 
set off a cascade of changes until one of the stable equilibria is reached (as suggested by arrows in the figure). ${ }^{3}$

Note that the location of equilibria may vary across countries because the distribution of critical mass points varies. This will be the case if the distribution of income varies, but the structure of educational borrowing, regulation of fees, and so on also matter. Our argument is thus fully compatible with a continuous distribution of private and public funding as opposed to only two outcomes.

Figure 3. Network game of educational choice with two stable equilibria

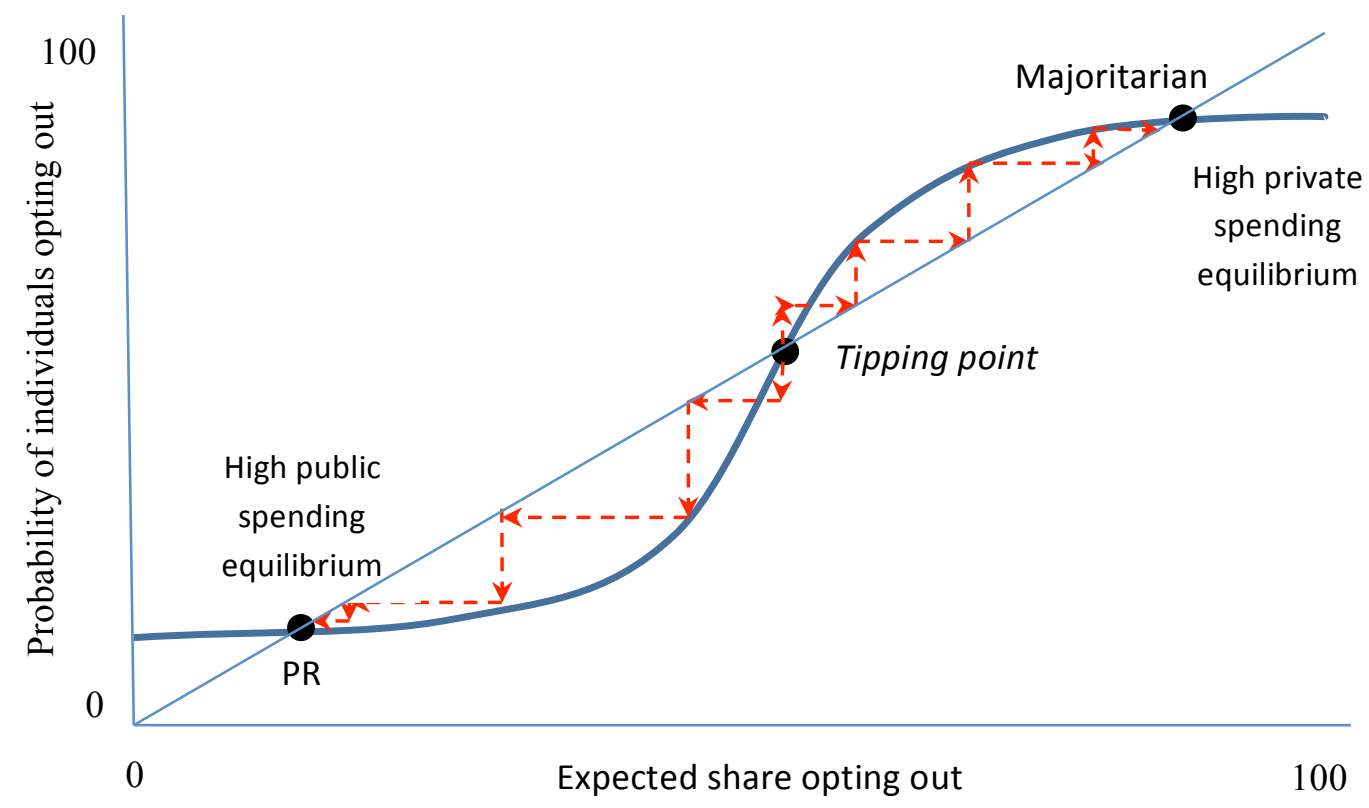

\subsection{Preferences for educational spending}

Given that the composition of spending is so different across countries we would expect the number of people above their critical mass points, where they oppose public spending, to vary systematically. As illustrated in Figure 3 the number will be greater in a system where most choose private schooling than in a system where most choose public). Empirically, we can capture the shares opting out by the division of private and public spending, so that average support for public spending should be rising in the share of total spending that is public.

\footnotetext{
${ }^{3}$ We have emphasized taxes and wage premia as the main mechanism creating strategic complementarities between educational choices (as people opt out of the public system, taxes to finance the public system fall, and so do the costs of opting out, etc. at the same time as the skill wage premium rises), but there may be a reinforcing social network effect. As more people opt out, the social acceptance of private schooling rises, and children left behind in the public system will tend to have a higher incidence of social and behavioral problems ("creaming"), which in turn undermines middle class support for the public system, etc. Of course, all these complementarities work to increase public spending if we are to the left of the "tipping point" in Figure 3.
} 
But there is another key implication of our argument, which is that the relationship between income and preferences for public spending varies with the composition of spending. While it is usually the case that those with high incomes who have reached, or are above, their critical mass point, and therefore opt out of the public system, will prefer less public spending, ${ }^{4}$ those who are clearly below this point will prefer to maintain public financing. In the short and medium term, the share of individuals opting out is given exogenously from the perspective of individuals. If education is a normal good (demand is rising in income), when the share of public financing is high, higher income is therefore expected to be associated with a more support for public education spending. Since even high-income people will fall short of their critical mass point, they are effectively deprived of the opportunity to opt out and the only way to satisfy their demand more and better education is to vote for an improvement in the quality of public higher education. In systems with a high private share, on the other hand, richer people will prefer to spend additional income on private education and oppose taxes for public education. ${ }^{5}$

The contingent relationship between income and preferences for spending is illustrated in Figure 4. Even though there are no inherent differences in the utility functions of people in different systems -- say, because of political culture or beliefs about the right to education -- at high levels of private spending the support for public spending is declining in income for most of the income scale, whereas at high levels of public spending the support for public spending is increasing in income for most of the income scale. No other theory of educational spending that we are aware of has this implication.

\footnotetext{
${ }^{4}$ A potential exception is when public spending on education is seen by the wealthy as insurance for their children in case they can no longer afford their education. We think this insurance motive is likely to be very weak, in part simply because movement from the private system back to the public is rare.

${ }^{5}$ Ansell (2008) has suggested that the support among the rich for public spending on higher education is higher when provision is low. But this assumes that financing is public, and then we agree since the rich prefer higher spending on education, especially when provision is low and disproportionately benefitting the rich. But as long as educational spending is redistributive (see footnote 1), then a higher private spending is preferable to public spending.
} 
Figure 4. The relationship between income and preferences for public spending on education depending on the composition of spending.

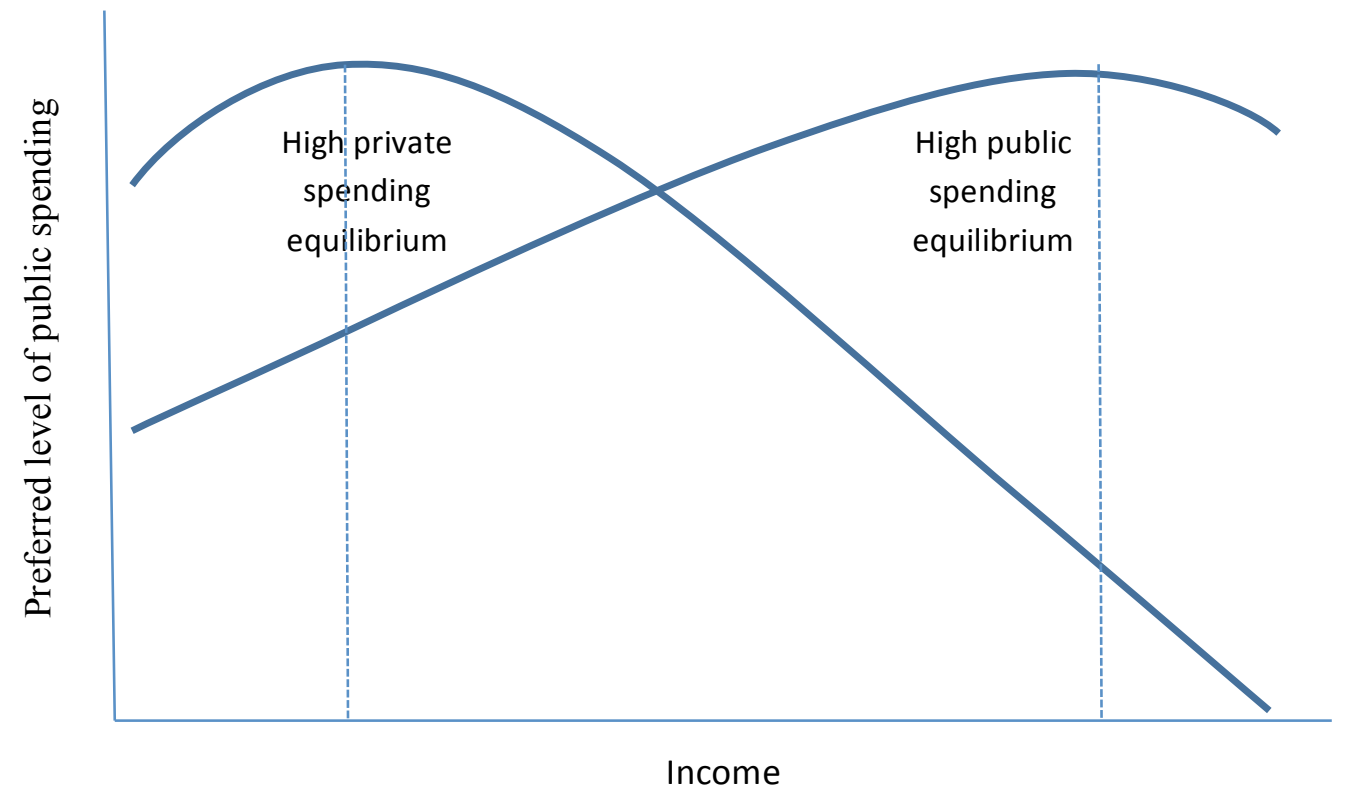

Note that the slope for the private equilibrium is drawn to be steeper, suggesting stronger class conflict. This is because those with low income cannot opt out of the public system and because public spending becomes de facto more redistributive as those with higher incomes do. In public systems, by contrast, those with lower income still benefit from the redistributive aspects of educational spending; even as they may oppose educational spending on higher education at a level that would satisfy the high expectations of middle- and high-income groups. An intriguing implication of our argument is therefore that class conflict, and hence partisan differences, are muted in public systems.

This may also suggest the possibility of center-right coalitions to fund higher education in publicfinanced systems. But for this to be true, the system must be firmly entrenched, and it does not speak to long-term institutional preferences. As we argue in the next section, in choosing a funding system the poor and the lower middle classes will prefer a public system when the burden of financing the system can be disproportionately placed on the wealthy, whereas the rich and upper middle classes will prefer a system that offers better private options. So if the right pushed for a fundamental change in the structure of funding in public-financed systems, we would expect the middle class to oppose.

\subsection{The choice of funding system in the postwar period}

As we argued above, once a funding system is in place it is likely to enjoy broad middle class support because of positive feedback effects, especially in public systems where most private education is squeezed out. But, again, these preferences are induced by entrenched educational institutions; they do not reflect "pre-strategic" preferences over the educational system itself. So setting up the system is likely to bring out the distributive conflicts we identified, following Ansell, in section 3.1. Since the 
middle class can go either way, a critical question is whether there are institutional incentives for the middle class to lean in one direction or the other. This would in effect solve the tipping point game.

Most of the rise in secondary and tertiary education occurred after the transition to democracy was completed the early $20^{\text {th }}$ century (in most of our cases). While it has been argued that prior religious control of education shaped public subsidization of private primary education (Ansell and Lindvall 2013), a critical variable for our purposes is simply whether political coalitions were in place that favored rapid growth in public spending, independent of whether some of this spending was funneled through religious schools. Before the Second World War as well as in the early postwar period, national systems of public education were hotly contested partisan affairs (Iversen/Stephens 2008; Busemeyer 2014). A key democratic institution that shaped the outcome was the electoral system. Proportional representation (PR) countries in continual Europe and Scandinavia quickly adopted almost entirely publicly funded systems, although this was true to somewhat lesser extent where Christian democracy and the church remained strong. By contrast, majoritarian England and its settler colonies reserved a much larger role for private schools and private spending on education.

One way to understand this contrast is suggested by Iversen and Soskice's $(2006 ; 2011)$ model of coalition formation, which implies that electoral institutions influence the likelihood of center-left or center-right coalitions. The argument is that in electoral systems based on proportional representation, the middle class, represented by a centrist party, is more likely to enter a coalition with the political representatives of the low income classes. This prediction rests on the notion that the rich can be forced to pay the lion share of public spending, usually outweighing any negative effects of such funding on the wages of the educated middle classes. As we have argued, once this this pro-spending coalition raises taxation and forces up the cost of opting out for the rich, the network logic kicks in and a stable equilibrium emerges where private schooling is merely a niche for the very wealthy. Public funding takes over.

In majoritarian systems the dynamic is different. Here the middle class typically has to choose between two parties, both appealing to the "median voter" but each incorporating distinct constituencies of either lower or higher income voters. In this setting the middle class has to be concerned what happens if parties deviate from their median voter platform, and here the calculus is different from the PR case. The center-left party, if it deviates, cannot be prevented from adopting a public system that imposes high taxes on the middle class (in addition to the upper classes), whereas if the center-right party deviates it will cut taxes and thus partially offset the loss of public spending. This enables more in the middle classes to pay for their own children's education. Alternatively, center-right parties will allow some mixture of private and public financing that will give the middle classes a measure of choice while keeping down costs (since those with higher income do not use the public system). As long as taxes are kept relatively low, and skilled wage premia high, a significant number of upper income parents will choose private alternatives. This encourages middle and upper-middle class groups to do the same, setting in motion the network logic we have modeled.

Our macro-level argument thus builds on the notion that public funding is initially a matter of traditional partisan politics. This continues to be true in majoritarian systems where the left is more likely than the 
right to support an increase in public spending. But there is twist to the story in PR systems because of the network effect. If the spending equilibrium is firmly shifted towards a public system, the middle and upper-middle classes concerned about high-quality education have no choice but to support better public schools. This in turn pushes right parties to favor more spending, despite their "first-best" choice being low spending. So PR tips the system to the left in Figure 4 above, even as it does not preclude subsequent center-right compromises over public spending intended to improve the quality of higher education (as opposed to more redistributive spending targeted to the lower and middle classes). This logic does not necessarily extend to other redistributive policies, and we think this highlights why education is such a unique policy domain. Yet, with more private alternatives being introduced in pensions and healthcare this could change.

Summarizing, our model implies the following testable hypotheses:

Hypotheses 1a (Macro level): We expect electoral institutions to influence patterns of spending on the macro level. The public share of education spending is hypothesized to be higher (lower) in PR (majoritarian) countries, controlling for other determinants.

Hypotheses $1 \mathrm{~b}$ (Macro level): Government partisanship is expected to matter, but only in the long term as it is by itself conditioned by the funding system and electoral institutions.

Hypothesis 2a (Micro level): The composition of funding has feedback effects on preferences for public education spending. In public-dominant educational systems we expect an increase in income to be associated with higher levels of demand for public education provision, whereas the opposite is expected in private-dominant educational systems (cross-level interaction effect).

Hypothesis $2 b$ (Micro level): The composition of funding also has feedback effects on average levels of support for increasing public education spending. In public systems, average levels of support should be higher, whereas the opposite holds in private systems.

The next section seeks to test these implications.

\section{Empirical analysis}

Following the theoretical discussion we test our argument in two steps. First, we analyze the macrolevel determinants of the share of private spending on education to determine whether electoral institutions are associated with different levels of private financing. Second, we study how electoral institutions feed back into public preferences and attitudes at the micro level. The second step is essential to our argument since it tests the causal mechanism of the network model that we introduced above. 


\subsection{Data}

For the macro analysis, we largely rely on the Comparative Political Dataset compiled by Armingeon et al. (2011). Additional data on the public share in education funding is taken from the OECD Education Statistics Database (accessed via OECD.stat). Our dependent variable is the public share of education spending (not spending as percentage of GDP as is common in existing scholarship (Ansell 2008, 2010; Busemeyer 2007, 2009; Castles 1989, 1998; Schmidt 2007)). The most important independent variable is an indicator of the type of electoral system given in Armingeon et al. (2011), based on previous work by Huber et al. (2004). A value of " 0 " indicates a PR system, a value of " 1 " a modified PR/mixed system, and a "2" a single-member, simple plurality system.

We control for several alternative explanations. Two variables are designed to capture the power resources of the political left. Wolf (2009) identifies union density as an important positive determinant of the public share in education funding. Unions have an interest in promoting public instead of private education in order to ensure open access to education for their membership. A related control is a measure of (short-term) government partisanship (also from Armingeon et al. 2011), for which higher values indicate a more left-ward oriented government. The standard expectation is that a more leftward oriented government to be associated with a larger public share, but short-term partisanship may not matter much because the policy (network) feedback effects reduce partisan differences once a particular public/private division of labor in education financing is established.

We also include gross enrolment levels in tertiary education in proportion to the age cohort (taken from the UNESCO database of education statistics) as a measure of demand. The expectation is that higher levels of enrolment should be associated with higher levels of spending although it may or may not spill over into a higher share of public spending depending on the elasticity of private demand. Related, we control for the total size of the public sector (total outlays as percentage of GDP from Armingeon et al. (2011)), because a larger public sector may capture political forces that are also important in explaining the public share of educational spending, yet not captured by any of our other controls. The causal relationship between these two variables is ambiguous, but including total public spending helps us control for the effect of unobserved variables and therefore reduces potential problems of omitted variable bias (the results are substantively unaltered if we exclude this variable).

Finally, we seek to control for the historical role of the Catholic Church in the development of educational systems in some countries (Ansell/Lindvall 2013) by including the population share of Catholics for the critical period from the turn of the $19^{\text {th }}$ to the $20^{\text {th }}$ century (taken from Barrett et al. 2001). The expectation is that a larger share of Catholics should be associated with a lower share of public funding and public education spending more generally (Castles 1989; Wolf/Zohlnhöfer 2009). However, it is important to remember that in many European countries with a strong Catholic heritage, independent religious schools in the primary and secondary education sector are actually financed with public monies (e.g. in France, Belgium, Italy and Ireland).

For the micro-level survey data, we use the ISSP Role of Government IV data. Fieldwork for this survey was administered in $2005 / 06$. The ISSP data is high quality and available for a large number of countries, 
and while the survey does not contain a question that specifically asks individuals for their preferences regarding the public/private division of labor in education financing, it contains one question that comes as close as any survey we are aware of: ${ }^{6}$

"Listed below are various areas of government spending. Please show whether you would like to see more or less government spending in each area. Remember that if you say ,much more', it might require a tax increase to pay for it." - „Government should spend money: Education"

Respondents' answers are coded in five categories (from 1 "Spend much more" to 5 "Spend much less"). We collapsed the five categories into a binary categorical variable that takes the value " 1 " if respondents state that government should spend "more" or "much more" on education and the value " 0 " in the remaining cases. The advantage of collapsing the five categories into two is that results of the statistical analyses are much more straightforward to interpret, while it does not affect the substantive results.

A disadvantage of the question wording is that it does not distinguish between different types of education (academic, vocational, basic, etc.), and it is not specifically about the division of labor between public and private sources of funding. Yet the assumption we have to make for this question to be a good proxy for our theoretical variable is fairly weak (see Figure 5). We essentially have to assume that underlying preferences mostly fall into the shaded cells in Figure 5. If some are in the non-shaded, off-diagonal cells it would attenuate the estimated effects of the observed variable - which is to say, it would make it harder to confirm our hypothesis -- but it would not bias the results in the wrong direction unless more than 50 percent of the observations fall into the off-diagonal cells. This seems a fairly innocuous assumption.

Figure 5. The assumed relationship between observed and unobserved preferences for educational spending.

Preferences for public spending on education (observed)

Preferences for the Lower public share of educational spending Higher (unobserved)

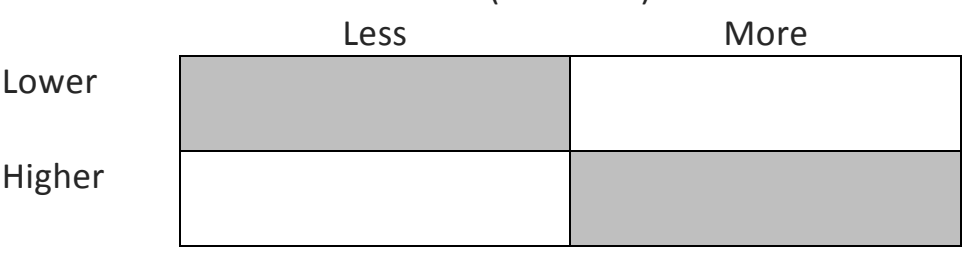

We next discuss our key explanatory variables. The first is income, given in income deciles in order to make relative income comparable across countries. As our model implies, without taking institutional

\footnotetext{
${ }^{6}$ The ISSP survey also contains a second question that we considered to use: "On the whole, do you think it should or should not be the government's responsibility to give help to university students from low-income families?" Compared to the alternative above, this question is less about public spending as such, but more about redistribution, since it asks specifically about government support for students from low-income families. In any case, the core findings of this paper (in particular the negative cross-level interaction between income and the existing division of labor) can be replicated using this alternative question (results available on request).
} 
context into account, we do not expect income to have a positive or negative significant effect on support for public education spending. Therefore, we include a cross-level interaction term between income and the prevailing private share of education spending. Furthermore, we include a number of control variables at the micro level. In contrast to income, educational background is expected to have a positive impact on support for more education spending. Having gone through a longer education may be an expression of a strong preference for such education, also for one's children. With regard to age, we expect a curvilinear relationship: Individual support for education spending increases up to a certain age, either because individuals are in education themselves or (expect to) have (young) children. Older people, in contrast, most likely prefer less spending on education and more on other social policies (Busemeyer et al. 2009). We include gender as an additional control. Since women are now more likely than men to attend college, yet still earning less than men, we may expect them to favor more public spending. In addition, we include a dummy variable that indicates whether respondents have children or not. ${ }^{7}$ The expectation is that having children increases support for education spending . Since there might be important differences in the impact of macro-level factors between parents and non-parents, we also split the sample in order to assess whether the effect of macro variables varies across subgroups. Finally, we include a number of categorical indicators of labor market status (full-time employed is the base category).

At the macro-level we control for the current level of public education spending to adjust for differences in the status quo. If people's preferences are affected by the status quo level of spending, which is a well-known issue in comparative opinion research, we need to control for differences in this level. In addition, we include the current level of income inequality (the net Gini index of inequality of household income taken from Solt (2009)). In line with the standard Meltzer and Richard (1981) model we expect inequality to be associated with a higher level of average support for public spending. The logic is that more than half have a below-mean income and will demand more spending when their income falls. We include the net Gini instead of the market inequality because the survey question asks about preferences for a change in spending, and here it is the post-fisc distribution that matters.

Because of problems of data availability, the composition of the two samples in terms of countries varies a bit. For the macro level analysis, we cover Australia, Austria, Belgium, Canada, Denmark, Finland, France, Greece, Ireland, Italy, Japan, the Netherlands, Norway, Portugal, Spain, Sweden, Switzerland, the US and the UK. Germany and New Zealand had to be excluded due to missing data either for private spending on education or tertiary enrolment. The period for which we have complete data is 1997-2008, although the unbalanced panel dataset also contains some observations for countries before 1997 . The ISSP dataset includes Germany and New Zealand, but excludes Austria, Belgium, Greece and Italy. In order to maximize the number of level-2 units (countries), we also include three Eastern European countries (the Czech Republic, Poland and Hungary). Yet, the results do not differ much whether we

\footnotetext{
${ }^{7}$ To be more precise, the variable in the ISSP dataset (HHCYCLE) captures the current composition of the respondent's household. Thus, respondents living in households with children are coded " 1 " and " 0 " otherwise. This does not take into account individuals with children not living with their parents anymore. Therefore, our estimate could underestimate the share of respondents with children attending university, but unfortunately, there is no better measure available in the dataset.
} 
include these or not. If we restrict the analysis to only the common set of countries our substantive results also stand. Yet we maximize $\mathrm{N}$ to generalize to as many advanced postindustrial OECD countries as possible.

\subsection{Methods}

The analysis of aggregate data poses serious, but well-known, methodological challenges. Pooled timeseries data are often plagued by serial autocorrelation of error terms within countries, panel-specific heteroskedasticity and contemporaneous correlation across units (countries) (Beck/Katz 1995, 1996; Franzese/Hays 2008; Kittel/Winner 2005; Kittel 2006). In our case the problem is aggravated by the fact that some of the independent variables, most importantly the electoral system and the historical share of Catholics, do not change over the time period we consider. Therefore, the effects of these independent variables would be suppressed if country fixed effects are used to pick up any unobserved country-specific confounders. Our (imperfect) solution to this problem is a) to provide a clear theoretical argument on the causal mechanisms linking electoral systems and policy output (see above) and b) to provide a large number of different model specifications to show the robustness of the findings.

More specifically, we employ three different model specifications: 1 . A model that uses panel-corrected standard errors (PCSEs, see Beck/Katz 1995, 1996) as well as an AR(1) process to correct for serial autocorrelation and a time trend variable. This model also includes a time trend variable to deal with potential problems of non-stationarity. 2. A model with PCSE and a lagged dependent variable (Beck/Katz 1995, 1996) that takes account of autocorrelation, but suppresses the explanatory power of other independent variables (Achen 2000). 3. A generalized least squares (GLS) model combined with an $A R(1)$ process to correct for autocorrelation of error terms.

With regard to the micro level analysis of preferences, we apply a simple multilevel logit regression. This model includes macro and micro level variables, taking into account the multilevel structure of the data when estimating standard errors (individuals nested within countries). Our theory predicts an association between macro level variables and average levels of support for education spending, where average levels in the dependent variable are conditioned by macro-level contexts, which is equivalent to a random intercept model. The second empirical implication of our model is an association between the private spending share and the income effect (cross-level interaction), which is equivalent to a randomslope model.

\subsection{Findings: Macro level}

Table 1 presents the findings from the macro-level analysis of the public spending share. The table shows that electoral institutions indeed have a significant impact on the public share in education financing in the expected direction (Hypothesis 1a). The public share is significantly lower in majoritarian systems. The variable on electoral institutions is the only one that is robust across all model 
specifications. The predicted effect of moving from a full PR to a full majoritarian system (recall from above that this indicator has three categories) is a reduction in the public share in spending of 9.8 (model 1), 9.9 (model 2) and 7.4 percentage points (model 3 ). The mean of the public spending share in the sample is 88.8 with a standard deviation of 8.2. Thus, the predicted effect has a magnitude of about one standard deviation.

The control variables behave largely as expected. Union density has a positive and sometimes significant effect as in Wolf (2009). A larger public sector is also associated with a higher share of public spending on education. In addition, we find some evidence for a positive association between gross tertiary enrolment and the public spending share, but it is not statistically significant. There is a statistically significant association between the share of Catholics and the public spending share, but, contrary to expectations, it is positive (Wolf and Zohlnhöfer (2009) have a similar finding). The reason for this puzzling association may be that, as mentioned above, independent religious schools in a number of Catholic European countries are actually financed with public monies. In any case, the association between electoral institutions and the public share remains robust and significant.

Government partisanship (left-oriented governments score higher on this indicator) tends to have a positive effect, but it is not statistically significant. However, it is important to remember that electoral institutions also influence the predominance of particular partisan coalitions in the long run (Iversen and Soskice 2011). Figure 6 confirms this by displaying a number of bivariate scatterplots between the longterm average cabinet share of conservatives and social democrats, respectively. A higher share of social democratic government parties is negatively associated with the private share of education funding, whereas the opposite holds for conservative government parties. These figures confirm that there is a strong relationship between partisan politics and education policies (Ansell 2010; Busemeyer 2007, 2009, 2014; Iversen/Stephens 2008; Wolf 2009), but it holds for the long-term rather than the short term, and it is conditioned by electoral institutions (Hypothesis $1 \mathrm{~b}$ ).

In table 2, we look at determinants of private spending on higher education (as percentage of GDP) instead of the share of public spending as a robustness check. Accordingly, the expected sign of the coefficient estimates switches, i.e. a larger public sector is shown to be associated with less private spending on education and the impact of union density is negative as well. However, as before, the variable on electoral institutions is the only one that is robust and statistically significant across all model specifications. The average predicted effect (from models 1 and 3 , table 2 ) of a change from full PR to full majoritarian system is an increase in private spending on higher education by 0.4 percentage points. The sample mean for this variable is 0.33 percent of GDP with a standard deviation of 0.4. Again, the predicted effect has the magnitude of about one standard deviation.

\footnotetext{
${ }^{8}$ This estimate is obtained by the following formula: Coefficient of independent variable / 1 - Coefficient on lagged dependent variable, as recommended by Kittel and Winner (2002) when using a LDV specification.
} 
Table 1: Macro Level: DV: Proportion of public spending on education

\begin{tabular}{|c|c|c|c|}
\hline \multirow[b]{2}{*}{ Dependent variable } & (1) & $(2)$ & (3) \\
\hline & \multicolumn{3}{|c|}{ Public share of education funding } \\
\hline Model specification & PCSE-AR(1) & PCSE-LDV & GLS-AR(1) \\
\hline \multirow[t]{2}{*}{ Public share, lagged level } & & $0.909 * * *$ & \\
\hline & & $(0.0413)$ & \\
\hline \multirow[t]{2}{*}{ Government partisanship } & 0.127 & 0.0127 & 0.0978 \\
\hline & $(0.237)$ & (0.124) & $(0.158)$ \\
\hline \multirow[t]{2}{*}{ Union density } & $0.129 * *$ & 0.00750 & $0.179 * * *$ \\
\hline & $(0.0540)$ & $(0.0113)$ & $(0.0546)$ \\
\hline \multirow[t]{2}{*}{ Public spending, $\%$ of GDP } & 0.0548 & $0.0634 * * *$ & -0.0147 \\
\hline & $(0.0789)$ & $(0.0147)$ & $(0.0718)$ \\
\hline \multirow[t]{2}{*}{ Gross tertiary enrolment } & 0.0693 & 0.000463 & 0.0401 \\
\hline & $(0.0484)$ & $(0.0137)$ & $(0.0280)$ \\
\hline \multirow{2}{*}{ Share of Catholics, ca. 1900} & $0.0589 * *$ & 0.00242 & $0.0641 * *$ \\
\hline & $(0.0267)$ & $(0.00384)$ & $(0.0264)$ \\
\hline \multirow[t]{2}{*}{ Majoritarian electoral system } & $-4.890 * * *$ & $-0.901 *$ & $-3.702 * * *$ \\
\hline & $(1.895)$ & $(0.469)$ & $(1.254)$ \\
\hline \multirow[t]{2}{*}{ Time trend (year) } & -0.204 & & \\
\hline & $(0.128)$ & & \\
\hline \multirow[t]{2}{*}{ Constant } & $484.9^{*}$ & 4.937 & $78.67 * * *$ \\
\hline & $(257.0)$ & (3.180) & $(4.356)$ \\
\hline Observations & 288 & 282 & 288 \\
\hline$R^{2}$ & 0.938 & 0.955 & \\
\hline Number of countries & 19 & 19 & 19 \\
\hline
\end{tabular}

Standard errors in parentheses

$* * * p<0.01, * * p<0.05, * p<0.1$ 
Table 2: Macro level: DV: Private spending on higher education (percentage of GDP).

\begin{tabular}{lccc}
\hline & $(1)$ & $(2)$ & $(3)$ \\
Dependent Variable & \multicolumn{1}{c}{ Private Spending } & on Higher Education, \% of GDP \\
\hline Model specification & PCSE-AR(1) & PCSE-LDV & GLS-AR(1) \\
Private spending, lagged & & $0.970^{* * *}$ & \\
level & & $(0.0288)$ & $4.26 \mathrm{e}-05$ \\
Government partisanship & -0.00249 & -0.00185 & $(0.00737)$ \\
& $(0.00419)$ & $(0.00327)$ & $-0.00825^{* * *}$ \\
Union density & $-0.00562^{* * *}$ & -0.000197 & $(0.00250)$ \\
& $(0.000887)$ & $(0.000150)$ & -0.00443 \\
Public spending, \% of GDP & $-0.00624^{* * *}$ & -0.000718 & $(0.00351)$ \\
& $(0.00195)$ & $(0.000903)$ & 0.00124 \\
Gross tertiary enrolment & -0.000103 & -0.000242 & $(0.00134)$ \\
& $(0.000988)$ & $(0.000237)$ & $-0.00271^{* *}$ \\
Share of Catholics, ca. 1900 & $-0.00241^{* * *}$ & $-0.000208^{* *}$ & $(0.00121)$ \\
& $(0.000573)$ & $(0.000100)$ & $0.111^{* *}$ \\
Majoritarian electoral & $0.177^{* * *}$ & $0.0231^{* * *}$ & $(0.0510)$ \\
system & $(0.0143)$ & $(0.00690)$ & \\
Time trend (year) & $0.0139 * * *$ & & $0.834^{* * *}$ \\
Constant & $(0.00381)$ & & $(0.221)$ \\
& $-26.98^{* * *}$ & $0.0859 *$ & 257 \\
Observations & $(7.554)$ & $(0.0460)$ & 18 \\
Rumber of countries & & & 239 \\
\hline
\end{tabular}


Figure 6: Partisanship in the long term and the private share in education financing.
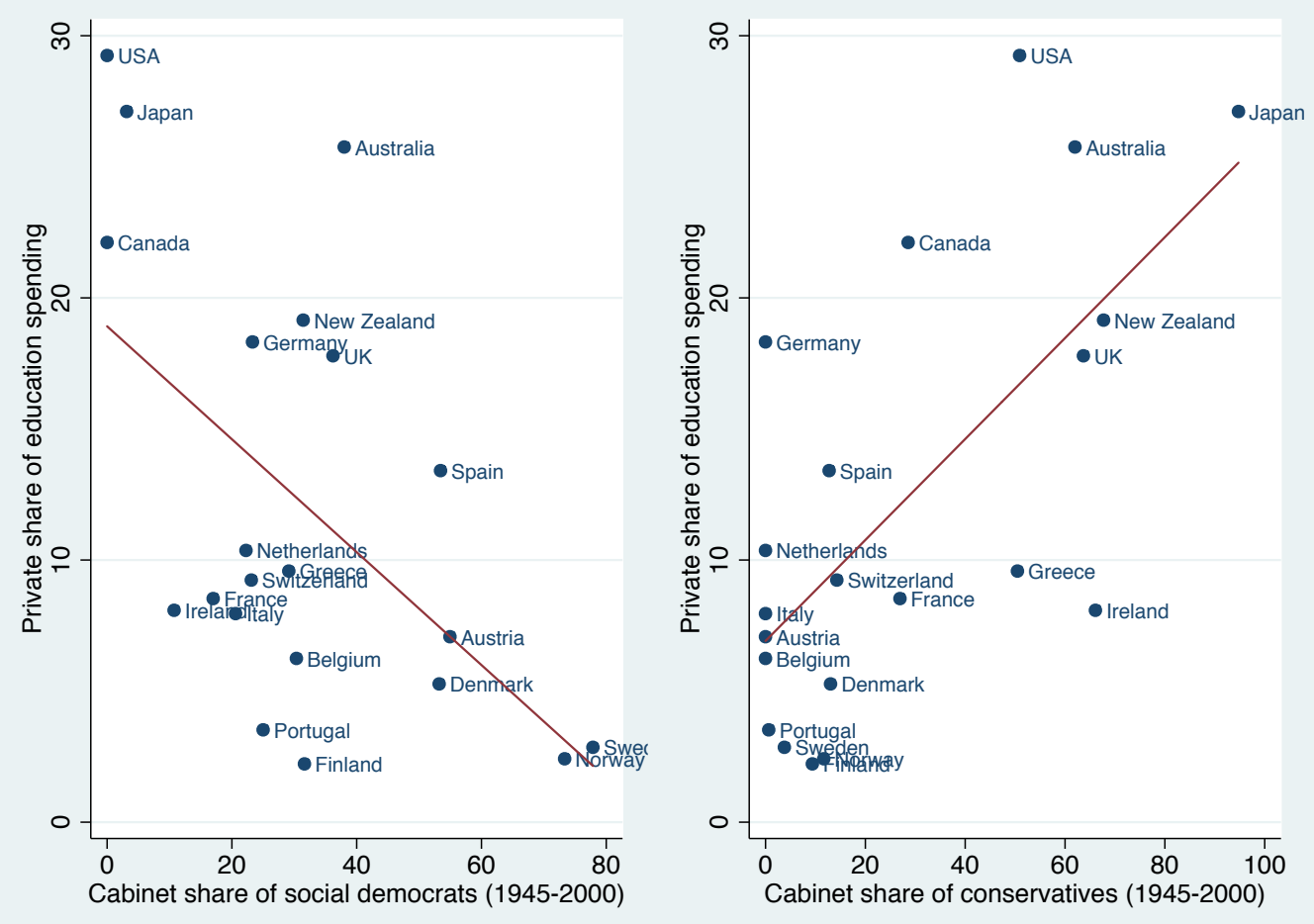


\subsection{Findings: Micro level}

In table 3, we look at the association between the prevailing division of labor in education financing and individual-level support for increased public spending on education. In general, the micro-level control variables perform mostly as expected. Without taking into account cross-level interaction effects, income does not have a significant impact on individual-level support for public education spending (model 1, table 3 ). This is worth reiterating because no other major policy area displays this kind of lack of association between income and preferences.

Educational background (years of education) has a positive, robust and statistically significant impact on support for more education spending. Women tend to be in favor of more education spending, but this effect is not statistically significant. We also find evidence for the expected curvilinear relationship between age and support in the case of support for public education spending. Labor market status is not a strong predictor of individual support for more education spending, except for the fact (unsurprising) that individuals who are still in the education system support further spending increases.

With regard to macro-level control variables, we find that the existing level of public education spending has a negative effect on support for further increases. We also find a robust positive and statistically significant association between existing levels of socio-economic inequality and average support for increasing public education spending. The predicted change in support for public education spending as a result of an increase in inequality from 22 to 36 points on the Gini index (roughly the difference between Sweden and the US) is an increase from the level of 53 percent to 83 percent. This is consistent with the notion that educational spending is redistributive and that the borrowing costs of private alternatives increase as income (and ability to provide collateral) decline. ${ }^{9}$

Our key finding is that there is a strong cross-level interaction between income and the private spending share. ${ }^{10}$ That is, the impact of household income on support for public education spending varies systematically with the prevailing private share of education spending. In public education systems, becoming richer is associated with an increase in support for higher public education spending, whereas it is associated with a decrease in support in private systems. This cross-level interaction is presented graphically in figure 7 , which shows the change in the marginal effect of a one-unit increase in income (at the mean) as it changes with the private spending share. The figure shows that income has a positive effect on support for public education for low levels of private spending share, although the effect is statistically significant only when the private spending share is close to zero. In contrast, the marginal effect of income turns negative and is statistically significant when the private spending share is larger than 20 percent. A similar cross-level interaction effect can be observed for the case of private spending for tertiary education only (model 3 , table 3 ).

\footnotetext{
${ }^{9}$ The estimate is based on model 1 from table 3. Calculations are based on simple logit regressions instead of multilevel models, because the SPost commands in Stata do not work with the latter.

${ }^{10}$ As an alternative, we included a cross-level interaction between individual income and inequality on the macro level. Because inequality and the private spending share are related, this cross-level interaction produces similar results: Increases in income are associated with lower support for public spending in inegalitarian societies and vice versa. Detailed results can be provided upon request.
} 
The reversal in the effect of income is quite remarkable. So far as we are aware this is true for no other spending area and is implied by no other existing model. The fact that the positive effect in public systems is relatively weak likely reflects that public spending is a composite of spending on lower-level education and subsidies targeted to poorer students, and spending on higher education and measures to ensure high quality (such as low teacher-students ratios). The latter is obviously more important to those with higher income. We would have liked to be able to differentiate clearly between the redistributive and "quality" aspects of educational spending in public systems, but the data does not allow us to do that. Thus, the effect of income on support for public spending includes preferences for both targeted and non-targeted spending. For systems with a large private component, by contrast, high-income individuals will tend to view all public spending as redistributive.

A second key finding is that there is a robust and significant association between the existing private share in education spending and average levels of support for increasing public spending. This association holds independent of whether we use the private spending share for all levels of education (models 1 and 2, table 3 ) or focus on tertiary education only (models 3 and 4, respectively). Increasing the private spending share from 5 percent (roughly the level of Norway) to 30 percent (the level of the US) is predicted to be associated with a decrease in support for more public education spending from 77 percent to 63 percent. A similar simulation for the case of private spending on tertiary education yields a reduction of support for public spending from 79 to 60 percent. Of course the network model implies that the causality runs in both directions since preferences for public spending will increase spending, even as they are also affected by such spending. Our data (from one year) cannot tease out this recursive relationship, but the results are consistent with the equilibrium predictions of the model.

As a further robustness test, we split the sample in two: parents (model 5) and non-parents (model 6) in order to address the question whether the effects are stronger in the first group compared to the second. The findings in the table show that by and large, the effects remain similar in direction and in terms of statistical significance in both subgroups despite the significant reduction in number of cases for the subgroup of individuals with children (although the coefficient estimate of the private spending share turns insignificant in model 5 of table 3). 
Table 3: Determinants of micro-level support for public education spending.
(1)
(2)
(3)
(4)
(5)
(6)

Dependent variable Support for more or much more government spending on education $(=1)$ vs. the same or less $(=0)$

\begin{tabular}{|c|c|c|c|c|c|c|}
\hline \multirow[t]{2}{*}{ Subsample? } & & & & & Children & No Children \\
\hline & \multicolumn{6}{|c|}{ Micro-level variables } \\
\hline \multirow[t]{2}{*}{ Income } & -0.000157 & $0.0516 * * *$ & -0.00326 & $0.0472 * * *$ & $0.0546^{*}$ & $0.0613^{* * *}$ \\
\hline & $(0.00980)$ & $(0.0179)$ & $(0.00990)$ & $(0.0169)$ & $(0.0294)$ & $(0.0228)$ \\
\hline \multirow[t]{2}{*}{ Gender (female=1) } & 0.0547 & 0.0570 & $0.0614^{*}$ & $0.0643^{*}$ & $0.167^{* *}$ & 0.0140 \\
\hline & $(0.0357)$ & $(0.0357)$ & $(0.0364)$ & $(0.0365)$ & $(0.0673)$ & $(0.0425)$ \\
\hline \multirow[t]{2}{*}{ Having children } & $0.312^{* * *}$ & $0.308 * * *$ & $0.306 * * *$ & $0.301 * * *$ & & \\
\hline & $(0.0392)$ & $(0.0393)$ & $(0.0401)$ & $(0.0401)$ & & \\
\hline \multirow[t]{2}{*}{ Years of education } & $0.0294 * * *$ & $0.0282 * * *$ & $0.0295 * * *$ & $0.0283 * * *$ & $0.0176^{*}$ & $0.0309 * * *$ \\
\hline & (0.00496) & $(0.00497)$ & $(0.00507)$ & $(0.00507)$ & $(0.00931)$ & $(0.00591)$ \\
\hline \multirow[t]{2}{*}{ Age } & $0.0165 * *$ & $0.0170 * * *$ & $0.0178 * * *$ & $0.0184 * * *$ & $0.0450 * * *$ & 0.0108 \\
\hline & $(0.00652)$ & $(0.00653)$ & $(0.00670)$ & $(0.00672)$ & $(0.0170)$ & $(0.00736)$ \\
\hline \multirow[t]{2}{*}{ Age, squared } & $-0.000141 * *$ & $-0.000148 * *$ & $-0.000152 * *$ & $-0.000161 * *$ & $-0.000459 * *$ & $-8.47 e-05$ \\
\hline & (6.77e-05) & $(6.78 e-05)$ & (6.97e-05) & (6.98e-05) & (0.000198) & $(7.45 e-05)$ \\
\hline \multirow[t]{2}{*}{ Part-time employed } & $0.107^{*}$ & $0.108^{*}$ & 0.0975 & 0.0987 & 0.150 & 0.0335 \\
\hline & (0.0619) & $(0.0620)$ & $(0.0643)$ & $(0.0644)$ & $(0.103)$ & $(0.0794)$ \\
\hline \multirow{4}{*}{$\begin{array}{l}\text { Less than part-time, } \\
\text { out of labor force } \\
\text { Unemployed }\end{array}$} & 0.0405 & 0.0453 & 0.0301 & 0.0368 & -0.0578 & 0.0926 \\
\hline & $(0.0628)$ & $(0.0629)$ & $(0.0641)$ & $(0.0641)$ & $(0.104)$ & $(0.0809)$ \\
\hline & 0.0558 & 0.0748 & 0.0415 & 0.0617 & 0.0463 & 0.0791 \\
\hline & $(0.0991)$ & $(0.0995)$ & (0.0997) & $(0.100)$ & $(0.168)$ & (0.124) \\
\hline \multirow[t]{2}{*}{ In education } & $0.523 * * *$ & $0.555^{* * *}$ & $0.507^{* * *}$ & $0.543 * * *$ & $0.786 * * *$ & $0.467^{* * *}$ \\
\hline & $(0.135)$ & $(0.136)$ & $(0.136)$ & $(0.137)$ & $(0.247)$ & $(0.165)$ \\
\hline \multirow[t]{3}{*}{ Retired } & 0.0374 & 0.0501 & 0.0293 & 0.0461 & -0.299 & 0.0509 \\
\hline & $(0.0677)$ & $(0.0679)$ & $(0.0690)$ & $(0.0693)$ & $(0.234)$ & $(0.0741)$ \\
\hline & \multicolumn{6}{|c|}{ Macro-level variables and cross-level interactions } \\
\hline Public education & $-0.315^{* *}$ & $-0.319 * *$ & $-0.327^{* *}$ & $-0.340 * *$ & $-0.328 * *$ & $-0.313^{* *}$ \\
\hline spending, \% of GDP & $(0.146)$ & $(0.149)$ & $(0.144)$ & $(0.147)$ & $(0.153)$ & $(0.154)$ \\
\hline Socio-economic & $0.122 * * *$ & $0.125 * * *$ & $0.143^{* * *}$ & $0.145^{* * *}$ & $0.127^{* * *}$ & $0.125 * * *$ \\
\hline inequality (Gini) & $(0.0296)$ & $(0.0300)$ & $(0.0327)$ & $(0.0332)$ & $(0.0313)$ & $(0.0312)$ \\
\hline Private share of & $-0.0375 * * *$ & $-0.0284 * *$ & & & -0.0195 & $-0.0304 * *$ \\
\hline $\begin{array}{l}\text { education spending, } \\
\text { all levels }\end{array}$ & $(0.0139)$ & $(0.0143)$ & & & $(0.0153)$ & $(0.0149)$ \\
\hline Income*private & & $-0.00294 * * *$ & & & $-0.00314^{* *}$ & $-0.00330 * * *$ \\
\hline spending share & & $(0.000840)$ & & & $(0.00140)$ & $(0.00106)$ \\
\hline Private share of & & & $-0.0218 * * *$ & $-0.0171 * *$ & & \\
\hline $\begin{array}{l}\text { education spending, } \\
\text { tertiary education }\end{array}$ & & & $(0.00772)$ & $(0.00795)$ & & \\
\hline income*private & & & & $-0.00154^{* * *}$ & & \\
\hline $\begin{array}{l}\text { spending share } \\
\text { (tertiary) }\end{array}$ & & & & $(0.000412)$ & & \\
\hline Constant & -1.593 & -1.795 & $-2.145^{*}$ & $-2.292 *$ & -2.127 & -1.679 \\
\hline
\end{tabular}




\begin{tabular}{lcccccc}
\hline $\begin{array}{l}\text { Variance } \\
\text { components }\end{array}$ & \multicolumn{7}{c}{ } \\
\hline Level-2 intercept & 0.4106 & 0.4167 & 0.4056 & 0.4122 & 0.4124 & 0.4288 \\
standard deviation & $(0.0671)$ & $(0.0680)$ & $(0.0682)$ & $(0.0693)$ & $(0.0721)$ & $(0.0710)$ \\
Intra-class & 0.0488 & 0.0502 & 0.0476 & 0.0491 & 0.0492 & 0.0530 \\
correlation & $(0.0151)$ & $(0.0156)$ & $(0.0153)$ & $(0.0157)$ & $(0.0164)$ & $(0.0166)$ \\
Log-likelihood & $-10,663.5$ & $-10,657.4$ & $-10,224.8$ & $-10,217.8$ & $-3,525.6$ & $-7,130.4$ \\
\hline $\begin{array}{l}\text { Observations } \\
\text { Number of }\end{array}$ & 18,971 & 18,971 & 18,218 & 18,218 & 6,690 & 12,281 \\
countries & 20 & 20 & 19 & 19 & 20 & 20 \\
\hline
\end{tabular}

Standard errors in parentheses

$* * * p<0.01, * * p<0.05, * p<0.1$ 
Figure 7: Graphical representation of the cross-level interaction between income and private spending share, dependent variable: support for public education spending.

ஜ-

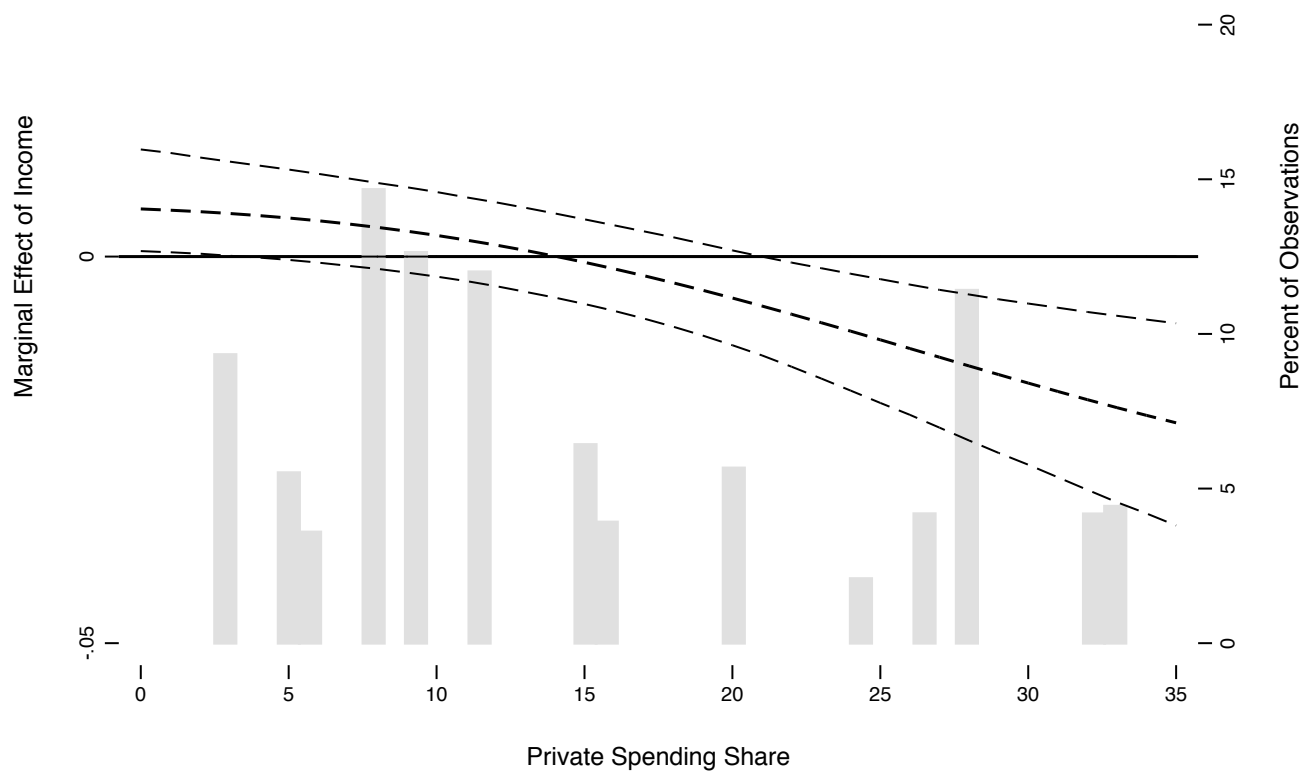




\section{Discussion and conclusions}

This paper addressed two pressing research puzzles: Why do countries vary significantly with regard to the share of private spending on education and why are these differences politically sustainable in the long term? Expanding the argument of Iversen and Soskice (2006), we argued that electoral institutions play a crucial role in shaping distributive coalitions. In PR systems, the center party representing the median voter can align with the representatives of the low-income classes to push for an education system in which the state dominates as provider and financier of education. In majoritarian systems, the median voter forms a coalition with the party of the upper income classes, leading to a larger share of private funding of education. Once in place, the funding system affects individual preferences for public spending because the greater the share of public spending the more expensive it is to opt out. If educational spending is a normal good this means that middle and upper-middle classes will vote for more public spending when such spending is high, but vote for less when it is low. These feedback effects explain why distinct spending equilibria are politically sustainable in the long run. We assessed the empirical validity of the argument both on the micro level of preferences and the macro level of aggregate data, and found considerable support for both conjectures.

Our theoretical perspective is rooted in the rational choice paradigm, although we underscore the social character of political preferences but underscoring the interdependencies of individual behavior. Still, there might be other reasons why the status of public and private education varies across countries. For example collective norms, values and expectations about the role of the state vis-à-vis private providers could reinforce (or counteract) the economic logic that we apply in our theory. We believe, however, that individual choices and preferences are to a large extent driven by material self-interest and network effects, and the empirical analysis confirms this expectation. We also take account for unexplained national differences in preferences to some extent by controlling for student enrolment and public spending levels.

Our argument has implications for how we explain inequality. First, and most obvious, the level and composition of public education has implications for the supply and distribution of skills. It is hardly an accident that publicly financed systems tend to have less wage inequality, and we suspect that the decline in the rate of growth in college graduates in the US, and the associated exceptional rise in wage inequality as documented by Goldin and Katz (2007), is closely associated with a rise in the number of middle and upper-middle income parents who opt to pay for children's education privately. Second, besides the question of financing, the institutional set-up of the education system might matter as well. In fact, institutional stratification within the public system may act as a functional equivalent to private education spending. Thus, private education spending is above average in countries with comprehensive secondary education systems and relatively open access to higher education (USA, Canada, the UK, but also Japan). Upper income classes might be willing to pay for the education of their children with the goal of effectively limiting access to (elite) higher education in institutionally less stratified systems. In contrast, access to higher levels of education is limited through institutions in education systems with a high degree of stratification, i.e. early tracking and a strong differentiation between academic and vocational education. The need of upper income classes to "price out" the middle or working class is less 
pressing in these cases and in fact, public spending on higher education can become a form of regressive redistribution from the low- to the high-income classes.

In general, the possibility of "opting out", either by purchasing private alternatives or by gaining exclusive access to superior public services, is likely to increasingly shape the politics of many policy areas ranging from pensions and healthcare to childcare and public safety. Since the 1980s new elements of choice and private options have been injected into many social policy areas, and we hope our approach will help cast light on how this might alter the politics of the welfare state. What has been an exceptional politics of education may become the norm. Theoretically we encourage a more explicit re-consideration of Hirschman's informal conjecture of an interaction between "exit" and "voice". 


\section{References}

Abrams, S., Iversen, T., \& Soskice, D. (2010). Informal Social Networks and Rational Voting. British Journal of Political Science 41 (2): 229-257.

Achen, C. (2000). Why Lagged Dependent Variables Can Suppress the Explanatory Power of Other Independent Variables. paper prepared for the Annual Meeting of the Political Methodology Section of the American Political Science Association. University of Michigan. Ann Arbor.

Andreß, H.J., Heien, T. (2001). Four Worlds of Welfare State Attitudes? A Comparison of Germany, Norway, and the United States. European Sociological Review 17 (4): 337-356.

Ansell, B. W. (2008). University Challenges: Explaining Institutional Change in Higher Education. World Politics, 60(January 2008), 189-230.

Ansell, B. W. (2010). From the Ballot to the Blackboard: The Redistributive Political Economy of Education. Cambridge: Cambridge University Press.

Ansell, Ben and Johannes Lindvall. 2013. "The Political Origins of Primary Education Systems: Ideology, Institutions, and Interdenominational Conflict in an Age of Nation-Building." American Political Science Review 107 (3): 505-525.

Armingeon, K., Engler, S., Potolidis, P., Gerber, M., \& Leimgruber, P. (2011). Comparative Political Data Set 1960-2008. Institute of Political Science, University of Berne.

Barrett, D.B., Kurian, G.T., \& Johnson, T. N. (2001). World Christian Encyclopedia: A Comparative Survey of Churches and Religions in the Modern World. Oxford: Oxford University Press.

Beck, N., \& Katz, J. (1995). What to do (and not to do) with Time-Series Cross-Section Data. American Political Science Review, 89(3), 634-647.

Beck, N., \& Katz, J. (1996). Nuisance vs. Substance: Specifiying and Estimating Time-Series-Cross-Section Models. Political Analysis, 6, 1-36.

Blekesaune, M., \& Quadagno, J. (2003). Public Attitudes toward Welfare State Policies: A Comparative Analysis of 24 Countries. European Sociological Review 19 (5): 415-427.

Boix, C. (1997). Political Parties and the Supply Side of the Economy: The Provision of Physical and Human Capital in Advanced Economies, 1960-1990. American Journal of Political Science, 41(3), 814-845.

Boix, C. (1998). Political parties, growth and equality: Conservative and social democratic economic strategies in the world economy. Cambridge: Cambridge University Press.

Breen, R., \& Jonsson, J. O. (2005). Inequality of Opportunity in Comparative Perspective: Recent Research on Educational Attainment and Social Mobility. Annual Review of Sociology 31: 223243. 
Busemeyer, M. R. (2007). The determinants of public education spending in 21 OECD democracies, 1980-2001. Journal of European Public Policy, 14(4), 582-610.

Busemeyer, M. R. (2009). Social democrats and the new partisan politics of public investment in education, Journal of European Public Policy. Journal of European Public Policy, 16(1), 107-126.

Busemeyer, M. R. (2012). Inequality and the Political Economy of Education: An Analysis of Individual Preferences in OECD Countries. Journal of European Social Policy, 22(3), 219-240.

Busemeyer, M. R. (2014). Skills and Inequality: Partisan Politics and the Political Economy of Education Reforms in Western Welfare States. Cambridge, New York: Cambridge University Press, forthoming.

Busemeyer, M. R., Goerres, A., \& Weschle, S. (2009). Attitudes towards redistributive spending in an era of demographic ageing: The rival pressures from age and income in 14 OECD countries. Journal of European Social Policy, 19(3), 195-212.

Busemeyer, M. R., \& Jensen, C. (2012). The impact of economic coordination and educational institutions on individual-level preferences for academic and vocational education. SocioEconomic Review, 10(3), 525-547.

Busemeyer, M. R., \& Nikolai, R. (2010). Education. In H. Obinger, C. Pierson, F. G. Castles, S. Leibfried \& J. Lewis (Eds.), The Oxford Handbook of the Welfare State (pp. 494-508). Oxford, New York: Oxford University Press.

Busemeyer, M. R., \& Trampusch, C. (2011). Review Article: Comparative Political Science and the Study of Education. British Journal of Political Science, 41(2), 413-443.

Castles, F. G. (1989). Explaining public education expenditure in OECD nations. European Journal of Political Research, 17, 431-448.

Castles, F. G. (1998). Comparative Public Policy: Patterns of Post-War Transformation. Cheltenham: Edward Elgar.

Culpepper, P. D. (2003). Creating Cooperation: How States Develop Human Capital in Europe. Ithaca, London: Cornell University Press.

Estevez-Abe, M., Iversen, T., \& Soskice, D. (2001). Social Protection and the Formation of Skills: A Reinterpretation of the Welfare State. In P. A. Hall \& D. Soskice (Eds.), Varieties of Capitalism: The Institutional Foundations of Comparative Advantage (pp. 145-183). Oxford, New York: Oxford University Press.

Finegold, D., \& Soskice, D. (1988). The Failure of Training in Britain: Analysis and Prescription. Oxford Review of Economic Policy, 4(3), 21-53.

Franzese, R. J., \& Hays, J. C. (2008). Interdependence in Comparative Politics: Substance, Theory, 
Empirics, Substance. Comparative Political Studies, 41(4-5), 742-780.

Hall, P. A., \& Soskice, D. (2001). An Introduction to Varieties of Capitalism. In P. A. Hall \& D. Soskice (Eds.), Varieties of Capitalism: The Institutional Foundations of Comparative Advantage (pp. 168). Oxford, New York: Oxford University Press.

Iversen, T., \& Soskice, D. (2001). An Asset Theory of Social Policy Preferences. American Political Science Review, 95(4), 875-893.

Iversen, T., \& Soskice, D. (2006). Electoral Institutions and the Politics of Coalitions: Why Some Democracies Redistribute More Than Others. American Political Science Review, 100(2), 165181.

Iversen, T., \& Stephens, J. D. (2008). Partisan Politics, the Welfare State, and Three Worlds of Human Capital Formation. Comparative Political Studies, 41(4-5), 600-637.

Jaeger, M. M. (2006). Welfare regimes and attitudes towards redistribution: the regime hypothesis revisited. European Sociological Review 22: 157-170.

Jaeger, M. M. (2009). United but Divided: Welfare Regimes and the Level and Variance in Public Support for Redistribution. European Sociological Review 25 (6): 723-737.

Kittel, B. (2006). A Crazy Methodology? On the Limits of Macro-Quantitative Social Science Research. International Sociology, 12(5), 647-677.

Kittel, B., \& Winner, H. (2002). How Reliable is Pooled Analysis in Political Economy? The GlobalizationWelfare State Nexus Revisited. MpifG Discussion Paper, 02/3.

Kittel, B., \& Winner, H. (2005). How reliable is pooled analysis in political economy? The globalizationwelfare state nexus revisited. European Journal of Political Research, 44, 269-293.

OECD. (2010). Education at a Glance 2010: OECD Indicators. Paris: Organisation for Economic CoOperation and Development.

Pfeffer, F. T. (2008). Persistent Inequality in Educational Attainment and its Institutional Context. European Sociological Review 24 (5): 534-565.

Schelling, T. C. (1978). Micromotives and Macrobehavior. New York: W.W. Norton \& Co.

Schmidt, M. G. (2007). Testing the retrenchment hypothesis: educational spending, 1960-2002. In F. G. Castles (Ed.), The disappearing state? Retrenchment realities in an age of globalisation (pp. 159183). Cheltenham, Northampton: Edward Elgar.

Sefton, Tom. (1997). The changing distribution of the social wage (Suntory and Toyota International Centres for Economics and Related Disciplines Occasional Paper No. 21). London: London School of Economics and Political Science. 
Soroka, S. N., \& Wlezien, C. (2010). Degrees of Democracy: Politics, Public Opinion, and Policy. Cambridge, New York: Cambridge University Press.

Stocké, V. (2007). Explaining Educational Decision and Effects of Families' Social Class Position: An Empirical Test of the Breen-Goldthorpe Model of Educational Attainment. European Sociological Review 23 (4): 505-519.

Streeck, W. (1989). Skills and the Limits of Neo-Liberalism: The Enterprise of the Future as a Place of Learning. Work, Employment \& Society, 3(1), 89-104.

Svallfors, S. (1997). Worlds of Welfare and Attitudes to Redistribution: A Comparison of Eight Western Nations. European Sociological Review 13 (3): 283-304.

Svallfors, S. (2004). Class, Attitudes and the Welfare State: Sweden in Comparative Perspective. Social Policy \& Administration 38 (2): 119-138.

Svallfors, S. (2010). Policy Feedback, Generational Replacement, and Attitudes to State Intervention: Eastern and Western Germany, 1990-2006. European Political Science Review 2 (1): 119-135.

Visser, J. (2011). ICTWSS: Database on Institutional Charac- teristics of Trade Unions, Wage Setting, State Intervention and Social Pacts in 34 Countries between 1960 and 2007, www.uva-aias.net/208

Wilensky, H. L. (1975). The Welfare State and Equality: Structural and Ideological Roots of Public Expenditures. Berkeley, Los Angeles, London: University of California Press.

Wolf, F. (2009). The Division of Labour in Education Funding: A Cross-National Comparison of Public and Private Education Expenditure in 28 OECD Countries. Acta Politica, 44, 50-73.

Wolf, F., \& ZohInhöfer, R. (2009). Investing in Human Capital? The Determinants of Private Education Expenditure in 26 OECD Countries. Journal of European Social Policy, 19(3), 230-244. 